\title{
Komunikasi Antarpribadi sebagai Alat untuk Pengurangan Ketidakpastian Anggota Komunitas RIOT Bandung
}

\author{
Glenn Petroliunanda ${ }^{1}$, Maylanny Christin ${ }^{2}$ \\ Universitas Telkom Bandung \\ petrol.glenn@gmail.com
}

Received: December 4, 2020; Revised: February 10, 2021; Accepted: February 22, 2021

\begin{abstract}
Abstrak
Komunitas Running Is Our Therapy atau biasa disebut komunitas RIOT adalah sebuah komunitas yang menghimpun orang-orang yang memiliki minat pada olahraga lari. Komunitas RIOT Bandung memiliki harapan bahwa dalam komunitas dapat terjadi komunikasi yang cair, berbaur, akrab, dan non formal sehingga dapat merangkul anggota tanpa batasan. Namun, fenomena yang saat ini terjadi yaitu anggota yang baru bergabung memiliki keraguan untuk bergabung dengan komunitas RIOT Bandung karena ketidakpastian dan keraguan untuk bergabung yang dialaminya. Hal tersebut menjadi tantangan bagi komunitas RIOT Bandung untuk melakukan komunikasi antarpribadi dengan anggota baru yang masih mengalami ketidakpastian, kekhawatiran, dan keraguan untuk mau bergabung dengan Komunitas RIOT Bandung. Penelitian ini bertujuan untuk mengetahui bagaimana komunikasi antarpribadi digunakan sebagai alat untuk pengurangan ketidakpastian anggota komunitas RIOT Bandung. Penelitian ini dikaji dengan menggunakan teori komunikasi antarpribadi dan teori pengurangan ketidakpastian. Penelitian ini menggunakan metode kualitatif dengan pendekatan studi fenomenologi pada anggota komunitas RIOT Bandung. Pengumpulan data dilakukan dengan teknik wawancara. Hasil yang peneliti dapatkan yaitu komunikasi antarpribadi yang dilakukan komunitas RIOT Bandung merupakan komunikasi antarpribadi yang nonformal dan membaur, bersifat apresiatif dan suportif, yang bertujuan agar dapat mengurangi ketidakpastian antar anggotanya. Komunikasi antarpribadi dinilai efektif dalam mengurangi ketidakpastian antar anggota. Kesimpulan dari penelitian ini, komunikasi antarpribadi yang dilakukan komunitas RIOT Bandung dinilai efektif untuk mengurangi ketidakpastian antar anggota, dan dinilai memiliki dampak yang besar dalam hubungan antar anggota komunitas. Komunikasi antarpribadi juga dinilai dapat membangkitkan semangat anggota komunitas karena merasa diberi dukungan oleh komunitas, sehingga anggota dapat merasa nyaman, diterima, dan dianggap oleh komunitas RIOT Bandung.
\end{abstract}

Kata Kunci: Komunikasi antarpribadi; Komunitas RIOT Bandung; Kualitatif; Pengurangan ketidakpastian; Studi fenomenologi.

Abstract
The Running Is Our Therapy community or commonly known as RIOT community is a
community that brings together people who have an interest in running. RIOT Bandung
community has the hope that in the community there can be fluid, mingled, intimate, and
non-formal communication so that it can embrace members without restrictions. 
However, the current phenomenon is the new members have doubts about joining the RIOT Bandung community because of their uncertainty and doubts experience. This is a challenge for the RIOT Bandung community to communicate interpersonally with new members who are still experiencing uncertainty, worry, and doubt about joining the RIOT Bandung Community. This study aims to determine how interpersonal communication is used as a tool to reduce the uncertainty of members of the RIOT Bandung community. This research was studied using interpersonal communication theory and uncertainty reduction theory. This study used a qualitative method with a phenomenological study approach to members of the RIOT Bandung community. Data collection was carried out by interviewing techniques. The results obtained by the researchers were that interpersonal communication carried out by the RIOT Bandung community was an interpersonal communication that was informal and blend in, appreciative and supportive, in order to reduce uncertainty. Interpersonal communication is considered effective in reducing uncertainty between members. The conclusion of this study, interpersonal communication carried out by the RIOT Bandung community is considered effective in reducing uncertainty between members, and is considered to have a big impact on the relationship between community members. Interpersonal communication is also considered to be able to arouse the enthusiasm of community members because they feel supported by the community, so that members can feel comfortable, accepted, and considered by the RIOT Bandung community.

Keywords: Interpersonal communication; RIOT Bandung Community; Qualitative; Reduction of uncertainty; Phenomenology studies.

\section{Pendahuluan}

Komunitas lari yang bernama Running Is Our Therapy atau yang biasa disingkat dengan nama RIOT Bandung merupakan komunitas yang menghimpun masyarakat yang memiliki hobi dalam berlari di Kota Bandung. Peneliti memilih untuk meneliti sebuah komunitas olahraga khususnya olahraga lari adalah karena meningkatnya minat masyarakat indonesia yang melakukan olahraga.

Data yang dilansir oleh Tirto.id memberitakan sebuah data dari Badan Pusat Statistik (BPS) yang menggambarkan sebuah statistik pada tahun 2015 terdapat 27,61\% persen penduduk Indonesia yang berusia lebih dari 10 tahun yang melakukan kegiatan olahraga. Meningkat dari tahun-tahun sebelumnya yaitu pada tahun 2009 terdapat $21,76 \%$, dan pada tahun 2012 terdapar $24,99 \%$ yang melakukan kegiatan olahraga. Hal tersebut menunjukkan bahwa minat olahraga masyarakat Indonesia berkembang dari tahun ke tahun.

Terdapat survei yang dilaksanakan oleh Sun Life Financial Asia Health Index tahun 2017 yang menunjukkan jenis olahraga yang diminati masyarakat Asia khususnya Indonesia. Pada survei tersebut menunjukkan data bahwa masyarakat di Asia lebih berminat pada olahraga lari sebanyak 54\%. Di Indonesia, masyarakat yang menyukai olahraga lari sebanyak $60 \%$. Setelah olahraga lari, olahraga sepeda dan renang adalah yang paling disukai oleh orang Asia dan khsusunya masyarakat Indonesia. Angka 
tersebut sangat besar untuk ukuran Asia dan Indonesia.

Komunitas RIOT Bandung merupakan salah satu komunitas di Kota Bandung yang menghimpun masyarakat yang memiliki minat pada olahraga lari. Menurut Ronny Kumara selaku wakil captain komunitas RIOT Bandung menyatakan bahwa keunikan komunitas RIOT Bandung jika dibandingkan dengan komunitas lari lain adalah setiap chapter RIOT di seluruh Indonesia terhubung dalam suatu struktur organisasi komunitas yang rapi, sehingga membuat hubungan antar chapter dapat terjalin dengan harmonis. Selain itu, program latihan komunitas RIOT Bandung lebih terprogram daripada komunitas lain, mulai dari easy run, long run, strength and conditioning, dan trail run.

Mulyana (2015) menyatakan bahwa kata lain yang berhubungan dengan komunikasi yaitu komunitas, yang menekankan pada kesamaan atau kebersamaan. Komunitas ialah sekumpulan pribadi yang mendiami lingkungan tertentu dan memiliki kepentingan yang sama (Iriantara, 2004). Kertajaya (2008) yang mengatakan bahwa komunitas digambarkan dengan sekelompok individu yang saling peduli lebih dari biasanya, dalam komunitas terjadi relasi pribadi yang erat antar anggota karena adanya kesamaan minat dan nilai.

Wakil captain RIOT Bandung Ronny Kumara mengatakan bahwa komunitas merupakan komunikasi yang bersifat non formal, yang seharusnya dapat memiliki hubungan antar anggota yang lebih akrab daripada organisasi formal. Karena menurut Ronny Kumara komunikasi yang terjadi seharusnya dapat lebih cair, non formal, berbaur, dan lebih akrab. Pada kenyataannya, masih terdapat anggota baru ataupun masyarakat yang ingin bergabung yang memiliki ketidakpastian yang menyebabkan mereka ragu untuk bergabung dan berbaur dengan anggota lain yang lebih dahulu bergabung, bahkan sampai tidak jadi bergabung.

Berdasarkan latar belakang yang dipaparkan oleh peneliti diatas, peneliti merumuskan suatu masalah dalam sebuah judul "Komunikasi Antarpribadi sebagai Alat untuk Pengurangan Ketidakpastian Anggota Komunitas RIOT Bandung”, dengan tujuan untuk mengetahui bagaimana komunikasi antarpribadi sebagai alat untuk pengurangan ketidakpastian anggota komunitas RIOT Bandung.

\section{Kerangka Teori}

\subsection{Komunikasi}

Komunikasi menurut Everett M. Rogers (dalam Mulyana 2015) merupakan sebuah proses pengalihan ide dari sumber pengirim pesan ke penerima, dalam tujuan untuk mengubah tingkah laku. Miller (dalam Suryanto, 2015:51) menyatakan bahwa komunikasi adalah pusat perhatian yang terdapat pada perilaku manusia yang memungkinkan pengirim pesan dengan sadar memindahkan pesan ke penerima untuk tujuan mempengaruhi perilaku.

Komunikasi juga dinilai sebagai proses sosial antar individu yang menggunakan simbol untuk memproduksi dan mengartikan makna dalam lingkungan (West dan 
Turner, 2008:5). Menurut Hanani (2017:17), manusia butuh berkomunikasi yang terdiri dari beberapa tujuan yang diantaranya adalah komunikasi sebagai alat untuk introspeksi diri, kepentingan keselamatan, memenuhi kebutuhan, membangun peradaban, membangun masyarakat global, sebagai alat resolusi konflik, sebagai media kebahagiaan, dan komunikasi untuk lintas generasi.

\subsection{Komunikasi Antarpribadi}

Komunikasi antarpribadi ialah komunikasi antara pribadi saling tatap muka yang setiap orang dapat terlibat menangkap reaksi orang lain secara langsung secara verbal dan non verbal (Mulyana, 2015:18). Devito (2011:252) menyatakan bahwa komunikasi antarpribadi ialah komunikasi yang terjadi antara dua individu ataupun kelompok kecil yang terjadi dalam kegiatan seharihari.

Ciri-ciri komunikasi antarpribadi menurut Mulyana (dalam Hanani 2017) adalah pihak yang melakukan komunikasi antarpribadi berada dalam jarak yang dekat dan pihak yang mengirim dan menerima pesan secara simultan dan spontan secara verbal dan non verbal.

Menurut Hanani (2017), komunikasi antarpribadi dibutuhkan dalam kehidupan sehari-hari manusia salah satunya untuk menjalin hubungan antar manusia dengan lebih bermakna melalui pendekatanpendekatan, juga untuk mengenal orang lain dengan karakteristik yang berbeda-beda. Riswandi (2009) menambahkan bahwa komunikasi antarpribadi memiliki beberapa tujuan yang salah satunya adalah untuk mengenal diri sendiri dengan orang lain dan menciptakan serta memelihara hubungan agar lebih bermakna, dan komunikasi antarpribadi juga dapat mengubah sikap dan perilaku orang lain.

\subsection{Teori Pengurangan}

Ketidakpastian

Berger dan Calabrese (dalam West dan Turner, 2008) menjelaskan ketika orang asing bertemu, fokus utama mereka yaitu untuk mengurangi ketidakpasitan dalam situasi tersebut karena pasti menyebabkan ketidaknyamanan pada hubungan. Mungkin mereka akan merasa tidak yakin dengan apa yang mereka pikirkan terhadap orang lain dan sebaliknya. Berger (dalam West dan Turner, 2008) menyatakan bahwa untuk berinteraksi secara lancar, seseorang perlu untuk mampu dalam memprediksi bagaimana lawan interaksi akan berperilaku.

$\begin{array}{ccr}\text { West dan } & \text { Turner } \\ \text { menyebutkan } & \text { bahwa } & \text { teori }\end{array}$
pengurangan ketidakpastian salah satunya didasarkan pada asumsiasumsi tentang orang mengalami ketidakpastian dalam lingkup antarpribadi, ketidakpastian merupakan keadaan yang tidak mengenakkan dan menimbulkan stress, dan komunikasi antarpribadi merupakan proses perkembangan melalui tahapan. Asumsi yang membingkai teori pengurangan ketidakpastian adalah komunikasi antarpribadi digunakan sebagai alat utama dalam mengurangi ketidakpastian (West dan Turner, 2008). 


\section{Metode Penelitian}

Metode yang digunakan pada penelitian ini adalah metode kualitatif. Metode kualitatif digunakan untuk mendapatkan suatu data yang mendalam dan bermakna. Dalam metode kualitatif, data disajikan dengan kata-kata yang bersifat naratif agar makna dari data yang ditemukan dapat disajikan dengan jelas.

Penelitian ini menggunakan studi fenomenologi yang menggambarkan secara langsung pengalaman manusia yang berhubungan dengan suatu objek. Dalam hal ini data yang didapatkan berdasarkan pengalaman langsung dari anggota Komunitas RIOT Bandung. Fenomenologi tidak diawali dan bertujuan untuk meenguji teori.

Paradigma yang peneliti gunakan adalah paradigma konstruktivisme yang memandan pengetahuan ini juga merupakan hasil dari konstruksi dari pemikiran subjek yang diteliti. Paradigma konstruktivisme dipilih karena untuk memahami realitas individu yang diteliti yang terbentuk oleh kehidupan sosial yang terjadi. Sehingga diharapkan hasil yang didapatkan merupakan hasil yang valid dan kredibel karena sesuai dengan pengalaman yang dialami oleh subjek penelitian.

Objek dari penelitian ini adalah komunikasi antarpribadi. Subjek dari penelitian ini adalah anggota Komunitas RIOT Bandung. Informan pada penelitian ini terdiri dari empat anggota Komunitas RIOT Bandung.

Teknik pengumpulan data pada penelitian ini adalah dengan teknik wawancara. Wawancara dilakukan dengan tujuan untuk mendapatkan data-data yang mendalam dari para informan. Wawancara penelitian dilakukan di Kota Bandung pada bulan September 2020. Teknik analisis data dilakukan dengan menggunakan model Miles dan Huberman yang terdiri dari reduksi data, penyajian data, dan penarikan kesimpulan/verifikasi. Teknik keabsahan data dilakukan dengan menggunakan triangulasi sumber, dengan sumber yang beragam, diharapkan dapat menghasilkan data yang lebih kredibel.

\section{Hasil Penelitian dan Pembahasan}

\subsection{Hasil Penelitian}

Sebelum peneliti mencari tahu mengenai komunikasi antarpribadi yang digunakan dalam mengurangi ketidakpastian, peneliti mencari tahu terlebih dahulu mengenai fenomena ketidakpastian yang dialami oleh anggota komunitas RIOT Bandung dan beberapa masyarakat Kota Bandung. Penelitian menunjukkan bahwa terdapat beberapa masyarakat yang memiliki hobi dalam berlari, namun memutuskan untuk tidak jadi bergabung dengan komunitas RIOT Bandung dengan alasan memiliki keraguan untuk bergabung. Anugrah sebagai seorang mahasiswa di Kota Bandung yang memiliki hobi berlari mengatakan bahwa dirinya sudah sering diajak untuk bergabung dengan komunitas RIOT Bandung, akan tetapi Ia selalu khawatir, ragu dan malu untuk bergabung dengan komunitas.

Selain Anugrah, informan lainnya Mohammad Zulfikar juga menyatakan bahwa ia merasa 
canggung untuk bergabung dengan orang-orang baru di komunitas RIOT Bandung. Hal ni menunjukan bahwa Anugrah dan Zulfikar yang sudah memiliki minat pada olahraga laripun tidak jadi bergabung di komunitas RIOT Bandung karena ketidakpastian yang dialaminya, Ia menambahkan bahwa dirinya merasa khawatir tidak diterima oleh anggota yang lain.

Informan lainnya yaitu Ilham yang sudah bergabung beberapa kali dengan komunitas RIOT Bandung, menyatakan bahwa ketika sudah bergabung beberapa kalipun Ia masih merasa canggung dan malu untuk berbaur dengan anggota-anggota yang sudah lama tergabung di komunitas. Ketiga informan tersebut memiliki pengalaman yang sama yaitu merasa malu, canggung, dan ragu untuk bergabung dengan komunitas RIOT Bandung.

Fenomena ketidakpastian yang dialami oleh informan sebelumnya yang mengatakan dirinya mengalami perasaan ragu, canggung, dan malu ketika bergabung. Hasil temuan penelitian mengenai bagaimana komunikasi antarpribadi yang dilakukan oleh komunitas RIOT Bandung untuk mengurangi ketidakpastian-ketidakpastian adalah dengan cara menyapa dan mengajak ngobrol anggota baru, melakukan komunikasi antarpribadi yang nonformal, komunikasi antarpribadi yang membaur, apresiatif, serta suportif.

Komunikasi antarpribadi yang dilakukan dinilai sudah efektif dan cukup baik untuk memotivasi dan merangkul, berdasarkan pengalaman para informan. Menurut Gusnandar sebagai salah satu anggota komunitas
RIOT Bandung mengatakan bahwa anggota komunitas mengurangi ketidakpastiannya dengan melakukan komunikasi-komunikasi yang suportif dengan komunikasi antarpribadi, yang dapat membuat anggota baru merasa terdukung dan diterima oleh komunitas. Ia juga menambahkan bahwa dengan komunikasi antarpribadi ketidakpastian yang dialami oleh anggota-anggota dapat berkurang dengan signifikan.

Berdasarkan jenisnya, menurut Gusnandar sebagai seorang anggota yang sekaligus sebagai officer komunitas RIOT Bandung, jenis komunikasi antarpribadi yang dilakukan oleh komunitas RIOT Bandung terbagi menjadi dua, yaitu komunikasi verbal dan komunikasi nonverbal. Komunikasi verbal yang dilakukan yaitu menyapa dengan nama anggota, menanyakan kabar, dibantu diperkenalkan kepada anggota lainnya, berbincang seputar pengalaman berlari, serta memberikan kalimat-kalimat motivasi untuk menyemangati ketika berlari.

Komunikasi nonverbal yang dilakukan yaitu berupa sikap para anggota yang menyambut dengan baik dan ramah, bersalaman ketika bertemu, dan melakukan tos-tosan atau high five ketika menyelesaikan lari. Komunikasi tersebut dilakukan untuk menjalin hubungan yang baik dan semakin intim, sehingga ketidakpastian yang dialami diantara anggota dapat semakin berkurang.

Informan bernama Gusnandar menyatakan bahwa komunikasi antarpribadi pasti efektif untuk mengurangi ketidakpastian. komunikasi antarpribadi yang 
dilakukan dinilai dapat membangkitkan semangat anggota baru. Sehingga setiap anggota dapat merasa disambut dengan baik dan didukung ketika berlari, juga merasa nyaman berada dalam lingkungan komunitas. Hasil lain menjelaskan bahwa komunikasi antarpribadi yang dilakukan dapat membuat anggota komunitas merasa terajak dan dibutuhkan untuk berada dalam komunitas RIOT Bandung, serta dapat membuat setiap anggota merasa dianggap sebagai anggota komunitas RIOT Bandung, tanpa ada perbedaan. Komunikasi antarpribadi yang dilakukan pada komunitas RIOT Bandung juga dinilai dapat menumbuhkan semangat para anggota dalam melakukan kegiatan berlari.

\subsection{Pembahasan}

Pengalaman ketidakpastian yang dialami oleh informan sehingga mereka memutuskan untuk membatalkan bergabung dengan komunitas RIOT Bandung merupakan kejadian yang sesuai dengan teori yang diungkapkan oleh West dan turner (2008) dimana pengalaman ketidakpastian ialah sebuah kondisi yang tidak mengenakkan dan menimbulkan stress. Hal tersebut juga yang membuat beberapa orang tidak jadi bergabung dengan komunitas RIOT Bandung, karena ketidakpastian yang dialaminya membuat dirinya merasa tidak enak dan tidak nyaman untuk bergabung dengan komunitas.

Setelah mendapatkan hasil dari wawancara dengan informan, dan dari jawaban-jawaban pada poin sebelumnya, peneliti dapat menarik kesimpulan bahwa komunikasi antarpribadi yang dilakukan di komunitas RIOT Bandung menurut para informan dinilai pasti efektif dalam mengurangi ketidakpastian antar anggota komunitas. West dan Turner (2008) mengungkapkan bahwa asumsi yang membingkai teori pengurangan ketidakpastian yaitu komunikasi antarpribadi digunakan sebagai alat yang utama untuk mengurangi ketidakpastian.

Dapat disimpulkan bahwa hasil wawancara dengan beberapa informan sesuai dengan teori yang disampaikan oleh West dan Turner yang menjelaskan bahwa komunikasi antarpribadi dapat digunakan sebagai alat utama dalam mengurangi ketidakpastian. Pada komunitas RIOT Bandung, ketidakpastian dapat berkurang dengan dilakukannya komunikasi antarpribadi antar anggota komunitas.

Sejalan dengan teori yang dikemukakan oleh Mulyana (2015) yang menyebutkan bahwa komunikasi antarpribadi yaitu kegiatan komunikasi yang dilakukan oleh pribadi dengan pribadi secara saling tatap muka sehingga memungkinkan setiap orang dapat terlibat dalam proses menangkap reaksi orang lain secara langsung, baik secara verbal dan nonverbal.

Berdasarkan hasil wawancara, peneliti juga menemukan bahwa anggota komunitas RIOT Bandung melakukan komunikasi antarpribada dengan dua cara yaitu dengan cara verbal dan nonverbal, dengan begitu komunitas RIOT Bandung telah melakukan komunikasi antarpribadi yang sesuai dengan teori yang disebutkan diatas. Sehingga komunikasi antarpribadi yang dilakukan dapat lebih efektif dalam 
mengurangi ketidakpastian antar anggotanya.

Komunikasi antarpribadi anggota komunitas RIOT Bandung telah memberikan hasil yang cukup baik bagi komunitas. Pernyataan tersebut disampaikan oleh informan saat peneliti melakukan wawancara. informan mengatakan bahwa komunikasi antarpribadi yang dilakukan dapat membuat anggota merasa diterima dalam komunitas, sehingga dapat membangkitkan semangat para anggota komunitas, dapat membuat anggota komunitas merasa disambut baik, kemudian merasa terdukung ketika berlari, merasa terajak, merasa dibutuhkan, serta dapat merasa nyaman ketika berada dalam komunitas RIOT Bandung. Komunikasi antarpribadi bisa berguna dalam mengubah sikap dan perilaku (Riswandi, 2009). Dalam teorinya, komunikasi antarpribadi dapat mengubah sikap dan perilaku individu lain. Riswandi juga menambahkan bahwa manusia banyak menggunakan waktu dengan tujuan mempersuasi orang lain melalui komunikasi antarpribadi.

Teori tersebut sejalan dengan hasil wawancara yang mengungkapkan bahwa dalam prosesnya, terjadi perubahan perilaku anggota dari yang pada awalnya memiliki ketidakpastian dan keraguan, menjadi berkurang, dan merasakan manfaat positif dari bergabung dengan komunitas RIOT Bandung.

\section{Simpulan}

Kesimpulan dari hasil temuan penelitian ini adalah berbagai cara komunikasi antarpribadi telah dilakukan oleh komunitas RIOT
Bandung dianggap efektif dan memiliki dampak yang besar untuk pengurangan ketidakpastian antar anggota komunitas RIOT Bandung. Dampak yang dirasakan dari anggota komunitas adalah setiap anggota dapat merasa dirangkul dan dianggap oleh komunitas.

Komunikasi antarpribadi dinilai sangat efektif untuk digunakan sebagai alat untuk mengurangi ketidakpastian antar anggota komunitas RIOT Bandung. Komunikasi antarpribadi juga dinilai dapat membangkitkan semangat anggota yang baru bergabung, sehingga setiap anggota dapat merasa nyaman berada di komunitas RIOT Bandung karena disambut dengan komunikasi antarpribadi yang baik, serta membuat anggota merasa didukung saat berlari, merasa diajak, serta merasa dianggap sebagai bagian dari komunitas RIOT Bandung tanpa ada perbedaan.

\section{Daftar Pustaka}

Buku:

Devito, J. A. (2011). Komunikasi Antar Manusia. Pamulang-Tangerang Selatan: Karisma Publishing Group.

Hanani, S. (2017). Komunikasi Antarpribadi: Teori \& Praktik. Yogyakarta: Ar-Ruzz Media.

Iriantara, Y. (2004). Community Relations: Konsep dan Aplikasinya. Bandung: Simbiosa Rekatama Media.Kertajaya, Hermawan. (2008). Arti komunitas. Jakarta: Gramedia Pustaka Utama.

Mulyana, D. (2015). Ilmu Komunikasi Suatu Pengantar. Bandung: PT Remaja Rosdakarya.

Riswandi, (2009). Komunikasi Antarpribadi dan Medianya. Jakarta: Graha Ilmu.

Suryanto. (2015). Pengantar Ilmu Komunikasi. Bandung: CV Pustaka Setia.

West, R., \& Turner, L. H. (2008). Pengantar Teori Komunikasi: Analisis dan 
Glenn Petroliunanda dan Maylanny Christin, Komunikasi Antarpribadi sebagai

Alat untuk Pengurangan Ketidakpastian...141-149

Aplikasi, Edisi 3. Jakarta: Salemba Humanika.

Internet:

Ayolariin. (2013 - 2020). AYOLARIIN!

Statistik. Diambil kembali dari https://ayolari.in:

https://ayolari.in/stats/

Gerintya, S. (2018, Januari 4). Lari, Indonesia, Lari! Diambil kembali dari tirto.id: https://tirto.id/lari-indonesialari-cCHS 